\title{
PENINGKATAN SIKAP ILMIAH PESERTA DIDIK MELALUI PENERAPAN MODEL DISCOVERY LEARNING
}

\author{
Yeri Yunita Melani Dewi ${ }^{1 *}$, Sri Irawati ${ }^{1}$, Irdam Idrus ${ }^{1}$ \\ ${ }^{1}$ Program Studi Pendidikan Biologi, Fakultas Keguruan dan Ilmu Pendidikan, Universitas Bengkulu \\ Email : yeriyunita07@gmail.com
}

\begin{abstract}
Abstrak
Penelitian ini bertujuan untuk meningkatkan sikap ilmiah peserta didik melalui model discovery learning di kelas VIII 6 SMPN 04 Kota Bengkulu. Jenis penelitian ini adalah penelitian tindakan kelas, penelitian ini terdiri dari dua siklus dengan setiap siklusnya terdiri atas tahap perencanaan, pelaksanaan tindakan, observasi, dan refleksi. Subyek penelitian adalah guru dan seluruh peserta didik kelas VIII 6 SMPN 04 Kota Bengkulu tahun ajaran 2017/2018. Variabel penelitian ini adalah model pembelajaran discovery learning dan sikap ilmiah peserta didik. Teknik pengumpulan data dalam penelitian ini yaitu observasi dan angket dengan instrumen berupa lembar observasi dan lembar angket. Hasil analisis data sikap ilmiah peserta didik pada siklus I diperoleh skor rata-rata 20,63 (Kurang) dan pada siklus II sikap ilmiah peserta didik mengalami peningkatan skor rata-rata yaitu 28,58 (Cukup). Dari hasil penelitian dapat disimpulkan bahwa model pembelajaran Discovery Learning dapat meningkatkan sikap ilmiah peserta didik kelas VIII 6 SMPN 04 Kota Bengkulu.
\end{abstract}

Kata Kunci : Discovery Learning, Sikap Ilmiah.

\begin{abstract}
The aim of this research is to describe the application of discovery learning model and the student's scientific attitude in seventh grade ${ }^{6}$ at SMPN 04 Bengkulu about human respitory system. The type of this research used the classroom action research with descritive method and divided in two cycles which each cycle has consisted to planning phase, the implementation of the action, observation, and reflection. This research involved the teachers and 26 students as the subject in seventh grade ${ }^{6}$ at SMPN 04 Bengkulu for academic year 2017/2018. The variable of the research has consisted to discovery learning model and the student's scientific attitude. The technique in collecting data in this research was observation from questionnaire sheet with used intsrument. The average score of data analyst for teacher's activity in the first cycle was 23 (good) and in the second cycle was 29 (good). Then the data for student's scientific attitude in the first cycle has gained with the average score 20,63 (less) and the second cycle has proved into 28,58 (enough). From the result of this research it can be concluded that the discovery learning model is be able to improve student's scientific attitude in seventh grade ${ }^{6}$ at SMPN 04 Bengkulu.
\end{abstract}

Keyword : Discovery Learning, Scientific Attitude 


\section{PENDAHULUAN}

Pembelajaran yang menekankan pada peserta didik aktif dalam menemukan konsep sendiri diantaranya adalah model discovery learning (Lestari \& Budiastuti, 2018). Pembelajaran berbasis penemuan atau discovery learning adalah model mengajar yang mengatur pengajaran sedemikian rupa sehingga anak memperoleh pengetahuan yang sebelumnya belum diketahuinya tidak melalui pemberitahuan, namun ditemukan sendiri. Dalam menemukan konsep, peserta didik melakukan pengamatan, menggolongkan, membuat dugaan, menjelaskan, menarik kesimpulan dan sebagainya untuk menemukan beberapa konsep atau prinsip dan informasi yang diperoleh berdasarkan pengamatan atau percobaan pada proses pembelajaran sehingga peserta didik dapat belajar aktif yang mengembangkan sikap ilmiah pada diri peserta didik (Cahyo, 2013).

\section{Pembelajaran IPA memiliki} karakteristik yaitu terdapat proses ilmiah, sikap ilmiah dan produk pengetahuan ilmiah. Kegiatan IPA melatih peserta didik untuk mengikuti proser ilmiah dalam mendapatkan pengetahuan. Sikap ilmiah diberdayakan melalui kegiatan proses ilmiah secara berkala. Sebagai produk diartikan sebagai hasil proses, berupa pengetahuan yang diajarkan dalam sekolah atau diluar sekolah ataupun bahan bacaan untuk penyebaran atau dissiminasi pengetahuan. Pembelajran IPA memberikan bimbingan kepada siswa untuk melakukan kinerja ilmiah (Trianto, 2014).

Dalam melakukan kerja ilmiah dapat menumbuhkan sikap ilmiah dalam diri peserta didik. Macam sikap ilmiah yang timbul bergantung dari banyaknya keterlibatan peserta didik dalam pembelajaran. Keterlibatan peserta didik berperan aktif dalam kerja ilmiah seperti mengamati, mencatat dan bertanya dapat menunjang perkembangan sikap ilmiah dalam diri peserta didik. Sikap dalam kerja ilmiah yang dilakukan dapat diamati dari keterlibatan peserta didik saat pembelajaran berlangsung (Margiastuti, 2015).

Dalam kegiatan pembelajaran langsung tidak terlepas dari proses penilain, adapun ruang lingkup penilaian dalam Kurikulum 2013 memiliki keterkaitan dengan pendekatan ilmiah (saintifik). Terdapat tiga komponen utama, yaitu penilaian sikap, pengetahuan, dan keterampilan. Ketiga komponen tersebut dilaksanakan dengan menggunakan teknik dan intstrumen penilaian yang berbeda-beda, tetapi tetap berimbang dan berfungsi saling melengkapi antara satu dengan yang lain. Hasil dari penilaian ketiga komponen tersebut dapat dijadikan sebagai tolak ukur dalam menentukan keberhasilan peserta didik dalam mengikuti proses pembelajaran. Namun kebanyakan yang terjadi di lapangan penilaian yang dilakukan hanya sebatas aspek pengetahuan saja, dan hal tersebut tidak sesuai dengan penilaian dalam kurikulum 2013 itu sendiri yang mencakup aspek penilaian yaitu, sikap, pengetahuan, dan keterampilan (Fadillah, 2014).

Berdasarkan pengalaman peneliti selama melaksanakan kegiatan magang 3 di SMPN 04 Kota Bengkulu, ada beberapa masalah yang ditemui dalam proses pembelajaran, yaitu: 1) Kegiatan pembelajaran masih berpusat pada guru sehingga keterlibatan peserta didik dalam kegiatan pembelajaran cenderung pasif, 2) pada saat melakukan praktikum mengamati irisan melintang akar dan batang tumbuhan monokotil dan dikotil, terlihat antusias peserta didik masih kurang karena masih menunggu perintah dari guru untuk belajar, hanya beberapa peserta didik dari setiap kelompok yang melakukan percobaan, mengemukakan 
pendapat dan menyampaikan hasil pengamatan tidak berdasarkan bukti yang kuat.

Hasil pengamatan tersebut menunjukan bahwa adanya permasalahan pada aspek sikap ilmiah peserta didik. Aspek sikap ilmiah memiliki indikator yaitu sikap ingin tahu, terbuka dan bekerja sama, kritis, serta sikap objektif atau jujur peserta didik saat mengikuti proses pembelajaran. Sikap ilmiah yang baik akan menjadi faktor pencapaian hasil belajar peserta didik menjadi baik pula, maka dari itu diperlukan suatu upaya perbaikan dalam model pengajaran yang dapat mendorong sikap ilmiah peserta didik.

Berdasarkan permasalahan yang diuraikan untuk meningkatkan sikap ilmiah peserta didik dibutuhkan model pembelajaran yang dapat mengembangkan sikap ilmiah peserta didik yaitu dengan menggunakan model pembelajaran yang memberi kesempatan kepada peserta didik terlibat aktif dalam proses pembelajaran melalui penyelidikan. Salah satu model yang dapat melibatkan peserta didik dalam proses pembelajaran adalah model Discovery Learning.

Model Discovery Learning sangat cocok untuk melibatkan peserta didik secara aktif dalam proses pembelajaran. (Permendikbud, 2014), model pembelajaran Discovery Learning mengarahkan peserta didik untuk memahami konsep, arti, dan hubungan, melalui proses intuitif untuk akhirnya sampai kepada suatu kesimpulan.

Penemuan konsep tidak disajikan dalam bentuk akhir, tetapi peserta didik didorong untuk mengidentifikasi apa yang ingin diketahui dan dilanjutkan dengan mencari informasi sendiri kemudian mengorganisasi atau mengkonstruksi apa yang mereka ketahui dan pahami dalam suatu bentuk akhir. Hal tersebut terjadi bila peserta didik terlibat. Dengan adanya proses penyelidikan yang dilakukan oleh peserta didik dalam pembelajaran, peserta didik telah dilibatkan dalam proses pembelajaran yang dilakukan guru maka akan terciptanya sikap ilmiah, seperti akan terciptanya rasa ingin tahu dalam peserta didik menemukan konsep, terciptanya sikap objektif atau jujur, mengemukakan pendapat berdasarkan pengamatan, terciptanya kerja sama didalam kelompok.

\section{METODE}

Jenis penelitian yang digunakan adalah Penelitian Tindakan Kelas dengan metode deskriptif. Subyek penelitian adalah guru dan seluruh peserta didik kelas VIII 6 SMPN 04 Kota Bengkulu tahun ajaran 2017/2018.

Teknik pengumpulan data yaitu observasi yang dilakukan untuk mengamati aktivitas guru dan sikap ilmiah peserta didik dan sikap ilmiah peserta didik dengan instrumen berupa lembar observasi dengan kategori baik, cukup, dan kurang, butir observasi dikembangkan dari dari langkah-langkah model discovery learning. Lembar angket digunakan untuk menilai sikap ilmiah peserta didik secara sendiri berdasarkan kegiatan pembelajaran yang telah dilakukan dengan memberi tanda $(\mathrm{V})$ pada empat kategori yaitu sangat setuju (4), setuju (3), tidak setuju (2), dan sangat tidak setuju (1). Butir pernyataan sikap ilmiah pada lembar observasi dan lembar angket dikembangkan berdasarkan dimensi dan indikator sikap ilmiah.

Teknik analisis data aktivitas guru dan sikap ilmiah peserta didik dianalisis secara deskriptif dengan cara mencari rerata dan kategori. Kategori rerata dan skor aspek pembelajaran dikategorikan dalam kategori baik, cukup, dn kurang. 


\section{HASIL DAN PEMBAHASAN}

1. Penerapan model discovery learning dan sikap ilmiah peserta didik pada siklus I dan siklus II

Berdasarkan hasil penelitian yang telah dilakukan dikelas VIII 6 SMPN 04 Kota Bengkulu dengan menerapkan model pembelajaran model discovery learning menggunakan dua siklus untuk meningkatkan sikap ilmiah peserta didik. Data dapat dilihat pada Tabel 1. Data hasil aktivitas peserta didik dan aktivitas guru.

Tabel 1. Data Hasil Aktivitas Peserta Didik Dan Aktivitas Guru

\begin{tabular}{|c|c|c|c|c|c|c|c|c|c|c|}
\hline \multirow{3}{*}{ Siklus } & \multicolumn{7}{|c|}{ Aktivitas Peserta Didik } & \multicolumn{3}{|c|}{ Aktivitas Guru } \\
\hline & \multirow{2}{*}{$\begin{array}{l}\text { Observasi } \\
\text { sikap } \\
\text { Ilmiah }\end{array}$} & \multirow{2}{*}{$\begin{array}{c}\text { Angket } \\
\text { sikap } \\
\text { ilmiah }\end{array}$} & \multirow[b]{2}{*}{ Total } & \multirow{2}{*}{$\begin{array}{c}\text { Rata- } \\
\text { rata }\end{array}$} & \multirow[b]{2}{*}{ Kategori } & \multicolumn{2}{|c|}{ Observer } & \multirow[b]{2}{*}{ Total } & \multirow{2}{*}{$\begin{array}{c}\text { Rata- } \\
\text { rata }\end{array}$} & \multirow[b]{2}{*}{ Kategori } \\
\hline & & & & & & 1 & 2 & & & \\
\hline I & 9,47 & 31,8 & 41,27 & 20,63 & Kurang & 23 & 23 & 46 & 23 & Baik \\
\hline II & 13,16 & 44 & 57,16 & 28,58 & Cukup & 29 & 29 & 58 & 29 & Baik \\
\hline
\end{tabular}

Berdasarkan Tabel 1. Diatas aktivitas guru berupa penerapan model discovery learning secara keseluruhan berkategori baik, siklus I dengan rerata skor 23 sedangkan pada siklus II meningkat dengan rerata skor menjadi 29. Peningkatan skor pada kegiatan pembelajaran siklus II ini seiring dengan dilakukannya perbaikan setiap tahapan model discovery learning dalam pembelajaran pada siklus I yang dinilai kurang maksimal. Hal ini sesuai dengan penelitian Widiadnyana (2014) yang mengatakan dengan perbaikan pembelajaran yang dilakukan oleh guru dapat menumbuhkan sikap ilmiah pada peserta didik. Sedangkan menurut Dalyono (1997) dalam Yunita (2014), mengatakan bahwa belajar bertujuan untuk mengubah sikap, dari negatif menjadi positif, tidak hormat menjadi hormat, benci menjadi sayang, dan sebagainya.

Sesuai dengan peranan guru menurut Rusman (2014), bahwa peranan guru sangat penting dalam proses pembelajaran untuk menentukan tingkat keberhasilan pendidikan karena mutu pendidikan yang dinilai dari prestasi belajar peserta didik ditentukan oleh guru.

2. Dimensi sikap ilmiah pada siklus I dan siklus II

Ada 6 dimensi sikap ilmiah yang dipilih untuk diamati dalam penelitian yaitu sikap ingin tahu, sikap respek terhadap data atau fakta, sikap berpikir kritis, sikap penemuan dan kreativitas, sikap berpikiran terbuka dan kerja sama, sikap ketekunan yang dapat diamati pada Tabel 2 berikut ini:

Tabel 2. Data dimensi sikap ilmiah peserta didik pada siklu I dan siklus II

\begin{tabular}{lcccc}
\hline \multirow{2}{*}{$\begin{array}{c}\text { Aspek sikap ilmiah peserta } \\
\text { didik }\end{array}$} & \multicolumn{2}{c}{ Siklus I } & \multicolumn{2}{c}{ Siklus II } \\
\cline { 2 - 5 } Ingin tahu & Rerata skor & Kategori & Rerata skor & Kategori \\
Respek terhadap data atau & 1,94 & Kurang & 2,98 & Cukup \\
fakta & 2,29 & Cukup & 2,95 & Cukup \\
Berpikir kritis & 1,79 & Kurang & 2,74 & Cukup \\
Penemuan dan kreativitas & 1,92 & Kurang & 2,97 & Baik \\
Berpikiran terbuka dan kerja & 2,7 & Cukup & 3,53 & Baik \\
sama & 2,97 & Cukup & 3,75 & \\
Ketekunan & & & & \\
\hline
\end{tabular}


Dimensi sikap ingin tahu pada siklus I didapatkan data dengan kategori kurang. Penilaian kategori kurang pada dimensi sikap ingin tahu tidak terlepas dari indikator sikap ingin tahu tersebut yang dinilai kurang, yaitu indikator perhatian pada obyek yang diamati dan indikator antusias dalam belajar. Data yang diperoleh sesuai dengan kenyataan pada saat proses pembelajaran. Dimana saat praktikum mekanisme pernapasan di siklus I membuat alat peraga mekanisme pernapasan, masih ada peserta didik yang tidak perhatian terhadap obyek yang sedang diamati hanya beberapa peserta didik dalam kelompok yang terlihat perhatian terhadap obyek yang diamati.

Pada siklus II dimensi sikap ingin tahu meningkat menjadi kategori cukup. Indikator sikap antusias ditinjau pertanyaan yang muncul dari perserta didik untuk mengetahui dan memperoleh informasi.

Indikator sikap perhatian pada obyek yang diamati terjadi peningkatan. Hal ini sesuai dengan kenyataan ketika praktikum setiap peserta didik harus menghitung frekuensi pernapasan masingmasing setelah melakukan kegiatan duduk, berdiri, berjalan, dan berlari, terlihat semua peserta didik dalam kelompok perhatian terhadap yang diamati.

Dimensi sikap respek terhadap data atau fakta, untuk dimensi sikap respek terhadap data atau fakta terdiri dari dua indikator yang diamati, pada siklus I sikap respek terhadap data atau fakta berkategori cukup, pada siklus II berkategori cukup. Dua indikator yang diamati mengalami peningkatan setiap siklusnya, seperti indikator sikap tidak memanipulasi data dan sikap mengambil keputusan sesuai fakta. Data yang diperoleh sesuai dengan kenyataan, pada saat proses pembelajaran peserta didik tidak memanipulasi data, seperti saat mengerjakan soal pada LKPD setiap kelompok mengisi jawaban LKPD berdasarkan hasil pengamatan yang telah dilakukan dan mengambil keputusan sesuai fakta.

Pada siklus I dari ke enam aspek sikap ilmiah, sikap kritis memiliki rerata skor paling kecil dengan kategori kurang dan terjadi peningkatan pada siklus II berkategori cukup. Terdapat 3 indikator yang dinilai pada dimensi sikap berpikir kritis diantaranya sikap meragukan temuan teman, menanyakan setiap perubahan/hal baru, tidak mengabaikan data meskipun kecil.

Pada siklus I terdapat didik yang masih memiliki sikap kurang perduli terhadap pendapat atau temuan peserta didik. Sedangkan pada siklus II peneliti membimbing peserta didik tidak percaya begitu saja dengan pendapat atau temuan temannya dengan cara meminta peserta didik menanggapi tanggapan dengan mendiskusikannya bersama Silvester (2012) mengungkapkan bahwa sikap berpikir kritis peserta didik dapat timbul apabila sering dilatih bagaimana peserta didik dalam membuat dan merumuskan pertanyaan-pertanyaan, merumuskan ide, menyampaikan pendapat, kemampuan mengidentifikasi objek-objek dan masalahmasalah dalam pembelajaran.

Indikator menanyakan setiap perubahan/hal baru pada siklus berkategori kurang dan terjadi peningkatan pada siklus II berkategori cukup, data yang diperoleh sesuai dengan kenyataan pada saat proses pembelajaran hanya beberapa peserta didik yang aktif bertanya terhadap hasil pengamatan yang didapatkan sedangkan pada siklus II peneliti membimbing setiap kelompok untuk aktif bertanya terhadap perubahan/hal baru yang ditemukan ketika pengamatan, seperti peneliti bertanya kepada peserta didik dalam setiap kelompok hal apa yang didapatkan setelah melakukan pengamatan dan 
memberikan penguatan jawaban yang benar agar memancing peserta didik untuk bertanya terhadap penguatan jawaban yang diberikan.

Indikator tidak mengabaikan mengalami perbaikan dari siklus I ke siklus II. Perbaikan aspek ini disebabkan adanya aktivitas pembimbingan peserta didik untuk tidak mengabaikan data yang didapatkan dengan cara mencatat semua data yang telah diamati. Kegiatan tersebut dilakukan pada praktikum menghitung frekuensi pernapasan peserta didik hanya mencatat hasil perhitungan.

Dimensi sikap penemuan dan kreativitas mendapatkan kategori kurang di siklus I. Pada siklus II, aspek tersebut mengalami menjadi kategori cukup. Ada dua indikator yang dinilai untuk dimensi sikap penemuan dan kreativitas yaitu sikap menggunakan fakta-fakta untuk konklusi (simpulan).

Dimensi sikap berpikiran terbuka dan kerja sama berkategori kurang dan terjadi peningkatan pada siklus II berkategori baik. Terdapat 4 indikator yang diamati pada dimensi ini, indikator yang pertama sikap menghargai pendapat/temuan orang lain. Pada siklus I dinilai cukup dan pada siklus II terjadi peningkatan berkategori baik, terlihat dalam proses pengamatan peserta didik menghargai pendapat/temuan dari teman kelompoknya.

Pada indikator sikap "merubah pendapat jika data kurang" mengalami peningkatan pada siklus II. Berdasarkan pengamatan, aspek ini diberdayakan dalam sintak Discovey learning pada sintak konfimasi data. Bimbingan dilakukan secara baik oleh guru, sehingga peserta didik mau merubah pendapat setelah adanya pembenaran.

Indikator yang ketiga dari sikap ilmiah yaitu menerima saran dari teman. Pada siklus I sudah dinilai cukup dan pada siklus II terjadi peningkatan menjadi baik, hal ini sesuai dengan kenyataan pada saat merancang alat peraga untuk mekanisme pernapasan terlihat dalam kelompok saling memberi saran dan menerima saran tersebut.

Indikator yang keempat pada sikap ilmiah yatu berpartisipasi aktif dalam kelompok. Pada siklus I dinilai sudah cukup dan pada siklus II terjadi peningkatan menjadi baik, di siklus I belum terlalu terlihat partisipasi aktif tiap peserta didik dalam proses pengamatan, namun ketika di siklus II baru terlihat partisipasi aktif peserta didik karena pada siklus II pengamatan yang dilakukanlah adalah menghitung frekuensi pernapasan tiap peserta didik. Dalam hal ini semua peserta didik terlibat untuk melakukan kegiatan seperti duduk, bediri, berjalan, dan berlari, agar diketahui frekuensi pernapasan masing-masing, sehingga adanya keterlibatan tersebut terlihatlah partisipasi aktif dari setiap peserta didik.

Dimensi sikap yang terakhir adalah dimensi sikap ketekunan dimana pada siklus I berkategori cukup megalami peningkatan pada siklus II dengan kategori baik. Indikator yang diamati adalah sikap mengulangi percobaan meskipun berakibat kegagalan. Pada siklus I masih berkategori cukup dan terjadi peningkatan pada siklus II berkategori baik . Data yang diperoleh sesuai dengan kenyataan pada saat proses pembelajaran, ketika membuat alat peraga mekanisme pernapasan setiap kelompok mengulangi percobaan ketika alat peraga yang mereka buat gagal.

Peningkatan sikap ilmiah peserta didik dari siklus I ke siklus II ini dapat terjadi karena disebabkan oleh perbaikan pembelajaran yang dilakukan guru. Dimana guru telah melakukan perbaikan dan mengoptimalkan dalam mengajar. Menurut Syah (2011) sikap peserta didik yang positif, terutama kepada guru dan mata pelajaran yang disajikan merupakan pertanda awal yang baik bagi proses belajar peserta didik tersebut. 
Peningkatan sikap ilmiah memberi dampak positif, seperti hasil belajar peserta didik menjadi meningkat, hal ini selaras dengan pendapat Dasta (2012) dalam Yunita (2014) yaitu penilaian sikap ilmiah dalam pembelajaran sains, penting dilaksanakan oleh karena dalam pembelajaran sains berkaitan dengan kemampuan, sehingga menjadi acuan peserta didik mampu atau tidak mampu pada pembelajaran. Sikap merupakan tingkah laku yang bersifat umum yang menyebar tipis diseluruh hal yang dilakukan peserta didik. Tetapi sikap juga merupakan salah satu yang berpengaruh pada hasil belajar peserta didik. Sikap ilmiah dapat dibedakan dari sekedar sikap terhadap sains, karena sikap terhadap sains hanya terfokus pada apakah peserta didik suka atau tidak suka terhadap pembelajaran sains. Tentu saja sikap positif terhadap pembelajaran sains akan memberikan kontribusi tinggi dalam pembentukan sikap ilmiah peserta didik.

\section{PENUTUP}

\section{Simpulan}

Sikap ilmiah peserta didik kelas $\mathrm{VIII}_{6}$ SMPN 04 Kota Bengkulu meningkat dari kategori kurang pada siklus I menjadi kategori cukup pada siklus II dengan pembelajaran model discovery learning.

\section{Saran}

Model discovery learning merupakan model pembelajaran yang tepat digunakan untuk meningkatkan sikap ilmiah peserta didik akan tetapi dalam menerapkan model ini hendaknya lebih memperhatikan dan membimbing peserta didik dalam setiap tahapannya, sehingga dengan adanya bimbingan dari seorang guru sikap ilmiah peserta didik ketika menemukan konsep saat proses pembelajaran akan mudah untuk dikembangkan.

\section{DAFTAR PUSTAKA}

Arikunto, S. (2006). Dasar-Dasar Evaluasi Pendidikan. Jakarta : bumi Aksara.

Cahyo, N. \& Agus. (2013). Panduan Aplikasi Teori-Teori Bealajar Mengajar. Yogyakarta : DIVA Press.

Fadillah. (2014). Implementasi Kurikulum 2013 Dalam Pembelajaran SD/MI, SMP/MTS, dan SMA/MA. Yogyakarta : AR-ruzz Media.

Lampiran (salinan) III Permendikbud Nomor 58 Tahun 2014 tentang Kurikulum 2013 SMP/MTS.

Lestari, S., \& Budaistuti, R.E. (2018). Implementasi Discovery Learning terhadap Keaktifan Siswa pada Mata Pelajaran Bahasa Inggirs Materi "Song" di SMA N Guntur Demak. Prosiding Seminar Nasional Mahasiswa Unimus. Volume 1. eISSN: 2654-766X.

Margiastutl, S. \& Nugraheni. (2015). Penerapan model guided inquiry terhadap Sikap ilmiah dan pemahaman konsep peserta didik Pada tema ekosistem. Dalam http://lib.unnes.ac.id/21017/1/400 1411004-S.pdf

Rosita, I. (2014). Meningkatkan Kerja sama Siswa Melalui Pembelajaran Kooperatif Tipe Think Pair Share. Dalamhttp://repository.uksw.edu/ bitstream/123456789/11889/2/PR OS Dewi\%20Anjani\%2C\%20Suciati \%2C\%20Maridi Profil\%20Keteram pilan\%20Kerjasama fulltext.pdf

Rusman. (2014). Model-model Pembelajaran. Jakarta : Rajawali Press.

Silvester, M. (2012). Peningkatan Kemampuan Berpikir Kritis Siswa kelas V DALENG Manggarai pada pokok Bahasan Globalisasi. Dalam https://anzdoc.com/peningkatan- 
kemampuan-berpikir-kritis-siswa-

kelas-v-sdi-dale.html

Sudijono, A. (2012). Pengantar Statistik Pendidikan. Jakarta : Rajawali Press.

Syah, M. (2011). Psikologi Belajar. Jakarta : PT. Raja Grafindo Persada.

Trianto. (2014). Model Pembelajaran Terpadu. Jakarta : Bumi Aksara.

Ismawati, F., Dwijananti, P., \& Nugroho, S. E. (2014). Penerapan Model Pembelajaram Conceptual Procedures Untuk Meningkatkan Curiosity dan Pemahaman Konsep Siswa.

Dalam https://journal.unnes.ac.id/nju/ind ex.php/JPFI/article/view/3047/310 $\underline{8}$

Widiadnyana, I. W. (2014). Pengaruh Model Discovery Learning Terhadap pemahaman konsep IPA dan Sikap Ilmiah Siswa SMP. Dalamhttps://media.neliti.com/me dia/publications/123048-IDpengaruh-model-discoverylearning-terhad.pdf

Yunita, Prima., \& Fakhruddin. (2014). Hubungan antara Sikap IImiah Siswa dengan Hasil belajar belajar fisika dikelas XI IPA Negeri Kampar.Dalam https://repository.unri.ac.id/jspui/ bitstream/123456789/1508/1/Jurn al\%20Frima\%20Yunita 